\title{
Infant ENOS haplotypes and maternal PIH
}

\author{
Yanamandra $\mathrm{K}^{1 *}$, Pramanik $A^{1}$, Bocchini Jr JA' ${ }^{1}$ and Dhanireddy $\mathrm{R}^{2}$ \\ ${ }^{1}$ Department of Pediatrics1 LSU Health Sciences Center, Shreveport, USA \\ ${ }^{2}$ Neonatology Section, Department of Pediatrics, UT Health Science Centre, Memphis, USA
}

\begin{abstract}
To determine whether the fetal genotypes influence maternal circulation during pregnancy and induce preeclampsia. Although the etiology of Pregnancy induced hypertension $(\mathrm{PIH})$ is unclear, endothelial dysfunction leading to hypercoagulability is a major contributing factor. Endothelial nitric oxide (eNO) serves as a vasodilator, relaxing smooth muscle, preventing platelet aggregation, and thus facilitating improved blood flow. Mutant eNO synthetase (eNOS) genotypes result in reduced nitric oxide levels. ENOS polymorphism in the mother has been considered to be a risk factor for preeclampsia. However, the off-springs have not been studied. The present study was undertaken to determine whether the fetal and / or maternal genotypes influence circulation during preeclampsia. ENOS SNPs assays were carried out on one hundred and seventy -five infants admitted to the Neonatal Intensive Care Unit at LSU Health Sciences Center. We found significant differences in eNOS gene frequencies between Caucasian and African American infants ( $\mathrm{p}=<0.001$ for combined SNPs). Our data also showed a marked increase ( 2 to 4 fold) in both SNP allele frequencies in Caucasian infants compared to controls ( $\mathrm{p}=<0.01)$. The elevations in African American infants with maternal history of PIH were even more pronounced $(\mathrm{p}=<0.001)$.
\end{abstract}

\begin{abstract}
Abbreviations: eNO: Endothelial nitric oxide, eNOS: Mutant eNO synthase, SNP: Single Nucleotide Polymorphism, PIH: Pregnancyinduced hypertension, HELLP: Hemolytic anemia, Elevated Liver enzymes and Low Platelet counts
\end{abstract}

\section{Introduction}

Pregnancy-induced hypertension (PIH) or preeclampsia remains a major cause of maternal and fetal morbidity and mortality, especially if untreated. Another disease prodrome, Hemolytic anemia, Elevated Liver enzymes and Low Platelet counts, or HELLP syndrome, for short, is a variant of preeclampsia. Preeclampsia also leads to abruptio placentae, which may be a leading cause of fetal death [1]. Pathophysiological changes, such as hypertension, hypovolemia, platelet dysfunction, disseminated intravascular coagulation, and enhanced vascular reactivity, may lead to endothelial cell-dysfunction [2].

Several investigators have reported various risk factors to the causes of this prenatal group of conditions including preeclampsia, PIH, ecclampsia, abruption placentae, and HELLP syndrome, [3-12]. Coagulopathy is one of the major risk factors, and several authors have reported genetic polymorphisms including vascular endothelial growth factor, prothrombin gene polymorphisms, methylenetetrahydrofolate reductase, factor $\mathrm{V}$ Leiden, several interleukins, and polymorphisms in the genes involved in nitric oxide synthesis, [3-12].

Constitutive nitric oxide (NO) production in endothelial cells increases during pregnancy and contributes to vasodilatation and blunting of vasopressor response [13,14]. Delacretaz et al., have shown that in women developing PIH, NO generation has been inappropriately low [6]. Ramsay et al. have shown the administration of NO donor improves blood flow in the uterine artery in normal early pregnancy and in women at high risk of developing PIH [7]. Yallampalli and Garfield [15], have shown that Inhibiting NO synthesis in rats during pregnancy produces hypertension, proteinuria, thrombocytopenia, and fetal growth retardation. Later, these studies were confirmed by Molnar et al. [16] in pregnant rats.
Endothelial nitric oxide (eNO) serves as a vasodilator, relaxes smooth muscle, prevents platelet aggregation, and facilitates improved blood flow and vascular tonicity. Reduced nitric oxide levels result in vasoconstriction and weak tone leading to decreased blood flow and hypoxia, hypertension, and thrombosis. Mutant eNO synthase (eNOS) genotypes result in reduced nitric oxide levels by decreasing the enzyme activity [17-20].

Arngrimsson et al. showed evidence of familial pregnancy induced hypertension locus in the eNOS-gene region [3]. Their data have supported the localization of a familial pregnancy induced hypertension susceptibility locus in the region of chromosome $7 q 36$ encoding the eNOS gene. Yoshimura et al. [8] have reported a significant association of variant Glu298Asp (G894T) in the eNOS gene with severe preeclampsia in humans, confirmed by others [5, 11\&12]. Yoshimura et al. reported that the missense Glu298Asp variant of the eNOS gene is also strongly associated with placental abruption in humans, a finding later confirmed by the studies of Hillermann et al. $[9,10]$.

We have observed interesting findings of novel alleles from our earlier eNOS studies on asthmatic patients [21]. We also found that eNOS genotypes frequencies differed significantly between Caucasians and African Americans [22,23]. Although several studies have been published on the preeclampsia, PIH, Abruptio placentae, studies on premature infants on these aspects correlating with maternal history of PIH were lacking. Because eNO plays an important role in vascular functions, with its deficiency leading to preeclampsia, HELLP

Correspondence to: Krishna Yanamandra. Associate Professor, Director of Biochemical \& Molecular Genetics Laboratory, Department of Pediatrics, LSU Health Sciences Center,1501 Kings Hwy,Shreveport, LA 71103,USA, Tel: 318675-5896; Fax: 318-675-6059; E-mail: kyanam@lsuhsc.edu

Key words: endothelial nitric oxide synthase, single nucleotide polymorphism, pregnancy induced hypertension, premature infants.

Received: April 20, 2017; Accepted: May 15, 2017; Published: May 18, 2017 
syndrome, abruptio placentae, and limited studies on infants with maternal history of PIH, we began investigating how the fetal and / or maternal genotypes influence maternal circulation during pregnancy and in infants with maternal history of PIH. We have conducted preliminary studies on the fetal influence of eNOS genotypes [24].

\section{Methods}

\section{Subjects and controls}

Peripheral blood samples from one hundred and seventy five (forty four infants with maternal PIH and one hundred and thirty one infants without) premature infants from LSUHSC, Shreveport, Louisiana, pediatric NICU facility were collected consecutively. This study was approved by the LSU Health Sciences Center, Shreveport, LA. Institutional Review Board.

\section{Methods}

Two eNOS gene SNPs (T-786C, and G894T) were studied by microplate-RFLP PCR method. DNA was isolated from patients and control samples using the QAIGEN DNA isolation kits.

Genotyping T-786C SNP assay: Genotyping assay was modified from Tsukada et al., [17] to suit the large number of samples in our laboratory. Briefly, micro plate PCR-RFLP assay was carried out in 10 micro liters with1 micro liter DNA, $3.25 \mathrm{mM} \mathrm{MgCl} 2,0.375 \mathrm{mM}$ dNTP mix, 10 X PCR reaction buffers II, 1 unit of Gold Taq polymerase from Applied Biosystems Corp., 0.015 micro molar primer mix with the following sequences: F: TGG AGA GTG CTG GTG TAC CCC A. R: GCC TCC ACC CCC ACC CTG TC. The following PCR parameters were used: Initial denaturation for $10 \mathrm{~min}$ at $94^{\circ} \mathrm{C}, 35 \mathrm{cycles}$ of $94^{\circ} \mathrm{C}$ for $30 \mathrm{sec}, 64^{\circ} \mathrm{C}$ for $30 \mathrm{sec}$, and $72^{\circ} \mathrm{C}$ for $60 \mathrm{sec}$., with the last extension at $72^{\circ} \mathrm{C}$ for $5 \mathrm{~min}$.

Following PCR, the 180bp product was digested by 2 units of Msp 1 restriction enzyme from New England Biolabs, with 1.2 micro liters of 10X Msp 1 buffer, at $37^{\circ} \mathrm{C}$ for 2 hours. Msp 1 digested PCR fragments were separated by electrophoresis on $2 \%$ agarose gel for 3 hours.

Scoring of eNOS T-786C genotypes: Genotypes were scored as follows: TT homozygotes with $140 \mathrm{bp}, 40 \mathrm{bp}$; CC homozygotes with $90 \mathrm{bp}, 50 \mathrm{bp}, 40 \mathrm{bp}$; TC heterozygotes with $140 \mathrm{bp}, 90 \mathrm{bp}, 50 \mathrm{bp}, 40 \mathrm{bp}$, electrophoretic bands using UV-fluorography and ethidium bromide staining. Genotypes were stratified according to the ethnicities, preterm and full term, and prematurity conditions.

Genotyping eNOS G894T (Glu298Asp) SNP assay: PCR composition is similar to the T-786C assay, except for the primer sequence which is as follows: F: AAG GCA GGA AGT GGA TGG A. R: CCC AGT CAA TCC CTT TGG TGC TCA. PCR conditions are as follows: Initial denaturation at $94 \mathrm{C}$ for $10 \mathrm{~min}$, followed by 35 cycles of $94 \mathrm{C}$ for $30 \mathrm{sec}, 63 \mathrm{C}$ for $30 \mathrm{sec}, 72 \mathrm{C}$ for $60 \mathrm{sec}$, with a final extension of $72 \mathrm{C}$ for $5 \mathrm{~min}$. Following the PCR, the 258bp product was digested for $2 \mathrm{hrs}$ at $37 \mathrm{C}$ with Ban II restriction enzyme, and electrophoresed on $2 \%$ agarose gel for $1.5 \mathrm{hrs}$. Scoring of G894T genotypes: Genotype 894GG with bands of $163 \mathrm{bp}, 85 \mathrm{bp}$; genotype $894 \mathrm{TT} 258 \mathrm{bp}$, and the heterozygote $894 \mathrm{GT} 258 \mathrm{bp}, 163 \mathrm{bp}, 85 \mathrm{bp}$. Genotypes are stratified according to the ethnicity, preterm, full term, and prematurity conditions.

\section{Results}

Baseline gene frequencies of both the SNPs in the control infants differed significantly between African Americans and Caucasians (Table. 1). Caucasian infants displayed significantly 2.5 -fold higher frequencies of mutant SNPs compared to African Americans, odds ratio 4 , (95\% CI 1.9-8.4, $\mathrm{p}=<0.001$, for $\mathrm{T}-786 \mathrm{C}$; odds ratio $2.3(95 \%$ CI 1-5.3, $\mathrm{p}=<0.05$ ), for G894T; and odds ratio 3.1, (95\% CI 1.8$5.4, \mathrm{p}=<0.001)$ for the combined SNPs. Baseline mean and median gestational ages and birth weights were not significantly different in patients and controls of either ethnicity (data not shown). SNP data on the two markers in infants with and without PIH in Caucasians are presented in Table.2, and in African Americans in Table.3.

In Caucasian infants, $-786 \mathrm{C}$ allele, and $894 \mathrm{~T}$ allele were 2-fold higher among the infants with maternal history of PIH compared to those without, odds ratio 2.2, (95\% CI 1.1-4, $\mathrm{p}=<0.01)$. Similarly, in the African American infants with maternal history of $\mathrm{PIH}$, two mutant SNPs allele frequencies were 3 -fold higher compared to those without, odds ratio 4.8, (95\% CI 2.6-8.6, $\mathrm{p}=<0.001$.

\section{Discussion}

The present data indicate the need for ethnic stratification because of the significant differences in the SNP genotype and allele frequencies between African American and Caucasian infants. We have demonstrated that the mutant $-786 \mathrm{C}$ and $894 \mathrm{~T}$ alleles were significant risk factors in the premature infants with maternal history of $\mathrm{PIH}$. This association was similar in both the Caucasian and African American premature infants. Earlier reports have shown that the mutant eNOS alleles lead to significant drop in the endogenous production of NO levels.

Inhaled nitric oxide (iNO) treatment as a therapeutic intervention has been suggested in persistent pulmonary hypertension of newborn cases as reported by Cook and Stewart [25] and in severe hypoxic respiratory failure [26]. Several investigators have reported the utility of L-Arginine supplementation in treating infants with necrotizing enterocolitis [27-30]. Our data suggests that the fetal genotypes may influence feto-maternal circulation contributing to PIH. If the infant inherits one copy from mother but not from father, that may become yet a homozygous situation in the feto-maternal circulation unit, even though the father may not have passed on the variant allele. This homozygous eNOS status in the feto-maternal unit may contribute to PIH in mother during stress of pregnancy. On the other hand, if father has passed on the variant allele but not the mother, the infant is only heterozygous and mother may not develop PIH. The genetic NOS status of the infant reveals endogenous production in the infant. Thus, we speculate that depending upon the infant genotype, inhaled NO or L-Arginine dosage regimen can be adjusted to prevent catastrophic damage by excess treatment. Furthermore, eNOS SNP testing in premature infants born to mothers with $\mathrm{PIH}$, particularly those with pulmonary hypertension is warranted.

\section{Conclusion}

Our data suggests that either fetal genotypes or their combination with maternal genotypes, may influence the development of hypertension in the mothers during pregnancy.

\section{Acknowledgement}

This study was undertaken by intramural funding of LSU Health Sciences Center. The authors gratefully acknowledge the expert technical assistance provided by Ms. Dawn Napper in Biochemical and Molecular Genetics Laboratory of LSU Health Sciences Center, Shreveport, Louisiana. 
Table 1. Distribution of T-786C and G894T genotypes and alleles in Caucasian and African American control infants.

\begin{tabular}{|c|c|c|c|c|c|c|}
\hline & Caucasians & Caucasians & African Americans & African Americans & OR $(95 \% \mathrm{CI})$ & pValue \\
\hline Markers & \# & Freq & \# & Freq & Caucasians vs. & \\
\hline T786C Genotypes & & & & & African Americans & \\
\hline $\mathrm{CC}$ & 4 & 0.09 & 1 & 0.01 & \multirow{8}{*}{$4(1.9-8.4)$} & \multirow{8}{*}{$<0.001$} \\
\hline $\mathrm{TC}$ & 14 & 0.3 & 10 & 0.12 & & \\
\hline TT & 29 & 0.61 & 73 & 0.87 & & \\
\hline Total Genotypes & 47 & 1 & 84 & 1 & & \\
\hline $\mathrm{CC}+\mathrm{TC}$ & 18 & 0.38 & 11 & 0.13 & & \\
\hline $\mathrm{C}$ & 22 & 0.23 & 12 & 0.07 & & \\
\hline $\mathrm{T}$ & 72 & 0.77 & 156 & 0.93 & & \\
\hline Total Alleles & \multirow[t]{2}{*}{94} & 1 & 168 & 1 & & \\
\hline G894T & & & & & \multirow{12}{*}{$2.3(1-5.3)$} & \multirow{12}{*}{$<0.05$} \\
\hline TT & 1 & 0.02 & 1 & 0.01 & & \\
\hline GT & 11 & 0.23 & 9 & 0.11 & & \\
\hline GG & 35 & 0.75 & 74 & 0.88 & & \\
\hline Total & 47 & 1 & 84 & 1 & & \\
\hline $\mathrm{TT}+\mathrm{GT}$ & 12 & 0.26 & 10 & 0.12 & & \\
\hline $\mathrm{T}$ & 13 & 0.14 & 11 & 0.07 & & \\
\hline G & 81 & 0.86 & 157 & 0.94 & & \\
\hline Total Alleles & 94 & 1 & 168 & 1 & & \\
\hline $\begin{array}{c}\text { CombinedGenotypes } \\
\text { CC/TT }\end{array}$ & 5 & 0.05 & 2 & 0.01 & & \\
\hline $\mathrm{TC} / \mathrm{GT}$ & 25 & 0.27 & 19 & 0.11 & & \\
\hline $\mathrm{TT} / \mathrm{GG}$ & 64 & 0.68 & 147 & 0.88 & & \\
\hline Total & 94 & 1 & 168 & 1 & \multirow{5}{*}{$3.1(1.8-5.4)$} & \multirow{5}{*}{$<0.001$} \\
\hline $\mathrm{CC} / \mathrm{TT}+\mathrm{TC} / \mathrm{GT}$ & 30 & 0.32 & 21 & 0.13 & & \\
\hline $\mathrm{C} / \mathrm{T}$ & 35 & 0.19 & 23 & 0.07 & & \\
\hline $\mathrm{T} / \mathrm{G}$ & 153 & 0.81 & 313 & 0.93 & & \\
\hline Total Alleles & 188 & 1 & 336 & 1 & & \\
\hline
\end{tabular}

Table 2. Distribution of T-786C and G894T genotypes and alleles in Caucasian PIH cases and controls.

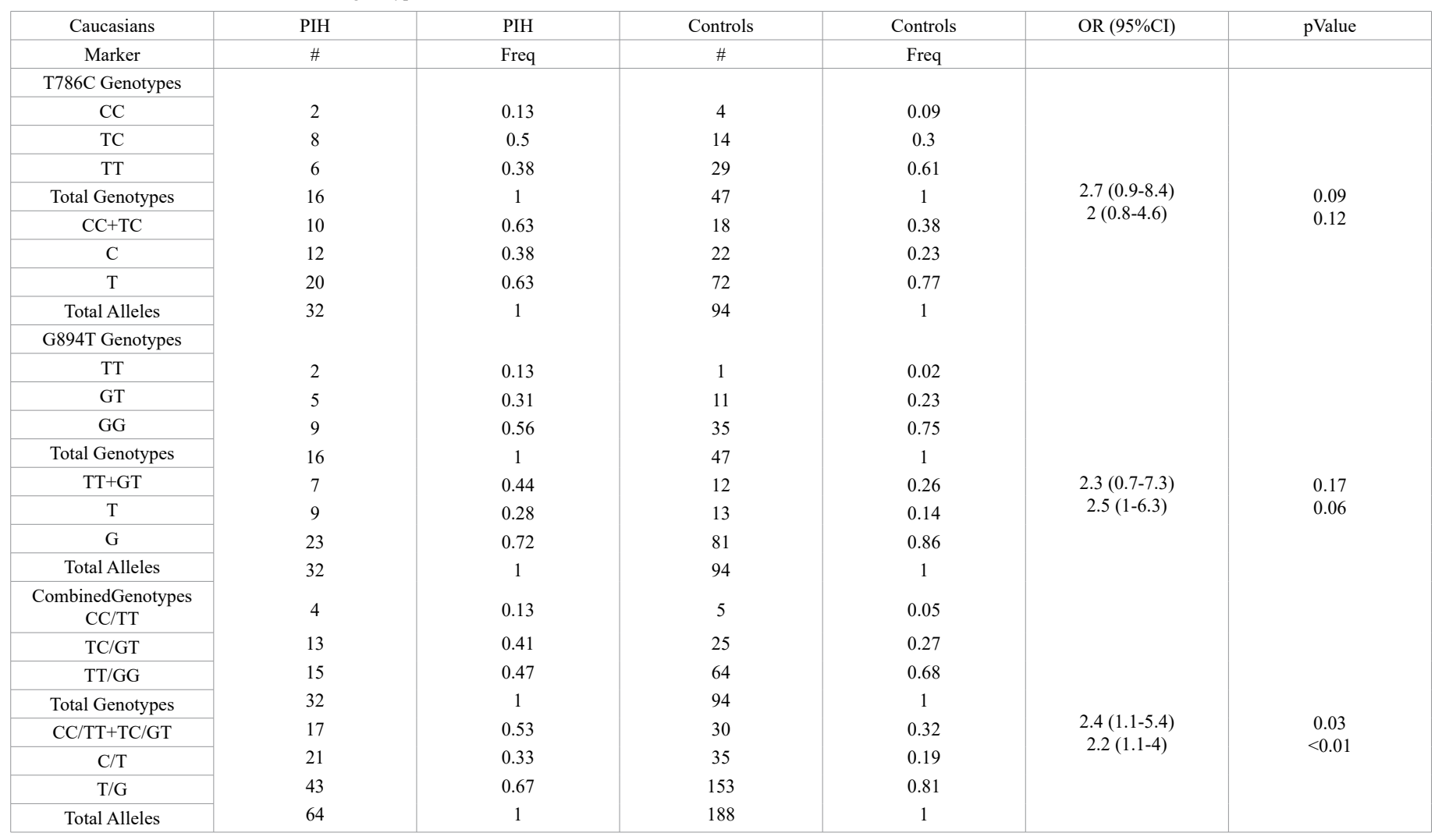


Table 3. Distribution of T-786C and G894T genotypes and alleles in African American PIH cases and controls.

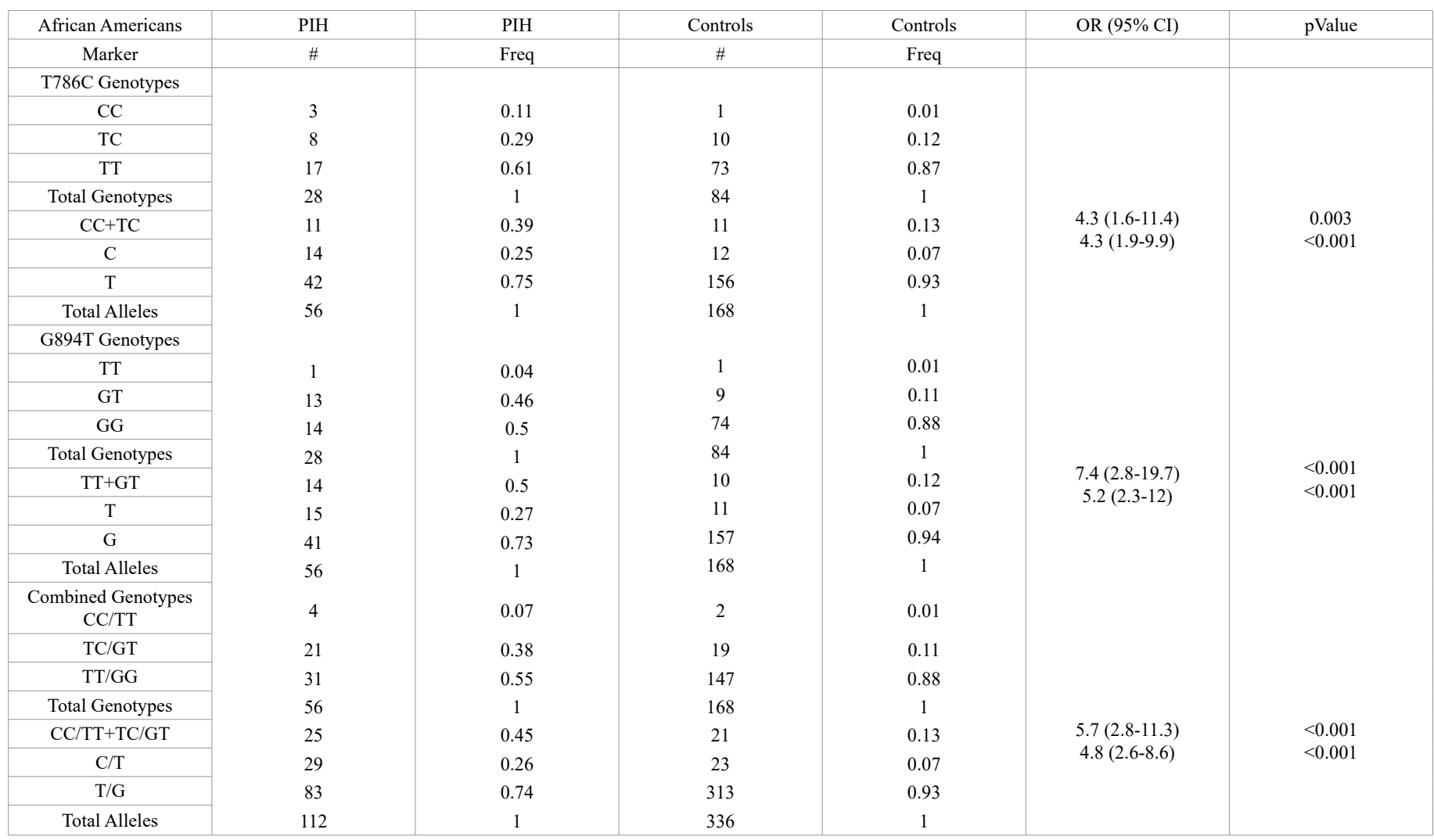

\section{References}

1. Fretts RC, Boyd ME, Usher RH, Usher HA (1992) The changing pattern of fetal death, 1961-1988. Obstet Gynecol 79: 35-39. [Crossref]

2. Roberts JM, Redman CW (1993) Pre-eclampsia: more than pregnancy-induced hypertension. Lancet 341: 1447-1451. [Crossref]

3. Arngrimsson R, Hayward C, Nadaud S, Baldursdottir A, Walker JA, et al. (1997) Evidence for a Familial Pregnancy-Induced Hypertension Locus in the eNOS-Gene Region. Am J Hum Genet 61:354-362 [Crossref]

4. Hingorani AD (2003) Endothelial nitric oxide synthase polymorphisms and hypertension. Curr Hypertens Rep 5: 19-25. [Crossref]

5. Serrano NC, Casas JP, Diaz LA, Paez C, Mesa CM, et al (2004) Endothelial NO synthase genotype and risk of preeclampsia: A multicenter case-control study. Hypertension 44: 702-707. [Crossref]

6. Delacretaz E, De Quy N, Weber B, Vial Y, Shulz PE, et al. (1995) Differential nitric oxide synthase activity in human platelets during pregnancy and preeclampsia. Clin Sci 88: 607-610 [Crossref]

7. Ramsay B, DeBelder A, Campbell S, Moncada S, Martin JF. (1994) A nitric oxide donor improves uterine artery diastolic blood flow in normal pregnancy and in women at high risk of preeclampsia. J Clin invest 24: 76-78 [Crossref]

8. Yoshimura T, Yoshimura M, Tabata A, Shimasaki Y, Nakayama M, et al. (2000) Association of the missense Glu298Asp variant of the endothelial nitric oxide synthase gene with severe preeclampsia. J Soc Gynecol Investig 7: 238-241 [Crossref]

9. Yoshimura T, Yoshimura M, Tabata A, Yasue H, Okamura H. (2001) The missence Glu298Asp variant of the endothelial nitric oxide synthase gene is strongly associated with placental abruption. Human Genet 108: 181-183. [Crossref]

10. Hillermann R, Carelse K, Gebhardt GS (2005) The Glu298Asp variant of the endothelial nitric oxide synthase gene is associated with an increased risk for abruptio placentae in pre-eclampsia. J Hum Genet 50: 415-419. [Crossref]

11. Fatini C, Sticchi E, Gensini F, Genuardi M, Tondi F, et al. (2006) Endothelial nitric oxide synthase gene influences the risk of preeclampsia, the recurrence of negative pregnancy events, and the maternal-fetal flow. J Hypertens 24: 1823-1829. [Crossref]
12. Sandrim VC, Palei ACT, Cavalli RC, Araujo FM, Ramos ES, et al. (2008) ENOS haplotypes associated with gestational hypertension or preeclampsia. Pharmacogenomics 9: 1467-1473. [Crossref]

13. Goetz RM, Morano I, Calvini T, Studer R, Holtz J. (1994) Increased expression of endothelial constitutive nitric oxide synthase in rat aortaduring pregnancy. Biochem Biophys Res Commun 205: 905-910. [Crossref]

14. Nathan L, Cuevas J, Chaudhuri G (1995) The role of nitric oxide in the altered vascular reactivity of pregnancy in the rat. Br J Pharmacol 114: 955-960. [Crossref]

15. Yallampalli C, Garfield RE. (1993) Inhibition of nitric oxide synthesis in rats during pregnancy produces signs similar to those of preeclampsia. Am J Obstet Gynecol 169: 1316-1320. [Crossref]

16. Molnar M, Suto T, Toth T, Hertelendy F. (1994) Prolonged blockade of nitric oxide synthesis in gravid rats produces sustained hypertension, proteinuria, thrombocytopenia, and intrauterine growth retardation. Am J Obstet Gynecol 170: 1458-1466. [Crossref]

17. Tsukada T, Yokoyama K, Arai T, Takemoto F, Hara S, et al. (1998) Evidence of association of the ecNOS gene polymorphism with plasma NO metabolite levels in humans. Biochem Biophys Res Commun 245: 190-193. [Crossref]

8. Yoon Y, Song J, Hong SO, and Kim JQ. (2000) Plasma nitric oxide concentrations and nitric oxide synthase gene polymorphisms in Coronary Artery Disease. Clin Chem 46: 1626-1630 [Crossref]

19. Song J, Yoon Y, Park KU, Park J, Hong YJ, et al. (2003) Genotype-specific influence on nitric oxide synthase gene expression, protein concentrations, and enzyme activity in cultured human endothelial cells. Clin Chem 49: 847-852 [Crossref]

20. Ahluwalia TS1, Ahuja M, Rai TS, Kohli HS, Sud K, et al. (2008) Endothelial nitric oxide synthase gene haplotypes and diabetic nephropathy among Asian Indians. Mol Cell Biochem 314: 9-17. [Crossref]

21. Yanamandra K, Boggs PB, Thurmon TF, Lewis D, Bocchini Jr.et al. (2005) Nove allele of the Endothelial Nitric Oxide Synthase gene polymorphism in Caucasian Asthmatics. Biochem Biophys Res Commun 335: 545-549 [Crossref]

22. Dhanireddy R, Boggs P, Yanamandra K, Napper D, et al. (2005) Association of endothelial nitric oxide synthase gene (ecNOS) haplotype with asthma in the Caucasians. Genet Med 7: A57 
23. Ursin SA, Yanamandra K, Boggs P, Napper D, Thurmon TF, et al. (2005) Ethnic differences in distribution of important asthma-associated polymorphisms. Genet Med 7: A64.

24. Yanamandra K, Vannemreddy P, Napper D, Pramanik A, Bocchini Jr.JA, et al. (2009) Mutant endothelial nitric oxide synthase (eNOS) genotypes in premature infants were more frequent with maternal pregnancy induced hypertension (PIH). Paper presented at the Pediatric Academic Societies (PAS) annual meeting held May 2-May 5 at Baltimore.

25. Cook LN, Stewart DL. (2005) Inhaled nitric oxide in the treatment of persistent pulmonary hypertension/ hypoxic respiratory failure in neonates: an update. $J \mathrm{Ky} \mathrm{Med}$ Assoc 103: 138-47 [Crossref]
26. Chotigeat U, Khorana M, Kanjanapattanakul W (2007) Inhaled nitric oxide in newborns with severe hypoxic respiratory failure. J Med Assoc Thai 90: 266-271. [Crossref]

27. Di Lorenzo M1, Bass J, Krantis A (1995) Use of L-arginine in the treatment of experimental necrotizing enterocolitis. J Pediatr Surg 30: 235-240. [Crossref]

28. Neu J1 (2007) Arginine supplementation for neonatal necrotizing enterocolitis: are we ready? Br J Nutr 97: 814-815. [Crossref]

29. Richir MC, Siroen MPC, van Elburg RM, Fetter WP, Ouik F, et al. (2007) Low plasma concentrations of arginine and asymmetric dimethylarginine in premature infants with necrotizing enterocolitis. Br J Nutr 97: 906-11. [Crossref]

30. Shah PS, and Shah VS. (2007) Arginine supplementation for prevention of necrotizing enterocolitis in preterm infants. Cochrane Database Syst Rev 3: CD004339. [Crossref]

Copyright: $@ 2017$ Yanamandra K. This is an open-access article distributed under the terms of the Creative Commons Attribution License, which permits unrestricted use, distribution, and reproduction in any medium, provided the original author and source are credited. 